\title{
THE SYNTHESIS OF NEW SPIROLACTONES FROM SUBSTITUTED ISATINS
}

\author{
Natalia Sucman ${ }^{\mathrm{a}}$, Vsevolod Pogrebnoi ${ }^{\mathrm{a}}$, Mykola Obushak ${ }^{\mathrm{b}}$ \\ Elena Melnic ${ }^{c}$, Victor Kravtsov ${ }^{\mathrm{c}}$, Fliur Macaeva* \\ anstitute of Chemistry of Academy of Sciences of Moldova, 3, Academy str., Chisinau MD-2028, Republic of Moldova \\ 'Ivan Franko National University of Lviv, 6, Kyryla i Mefodiya str., Lviv 79005, Ukraine \\ 'Institute of Applied Physics of Academy of Sciences of Moldova, 5, Academy str., Chisinau MD-2028, Republic of Moldova \\ *e-mail: flmacaev@cc.acad.md; phone (+373 22) 73 97 54; fax (+373 22) 739954
}

\begin{abstract}
Interaction of $N$-ethyl isatin 3 with dimethyl acetylenedicarboxylate in the presence triphenylphosphine has led to good selectivity of methyl 1'-ethyl-4-methoxy-2',5-dioxo-5H-spiro[furan-2,3'-indoline]-3-carboxylate 4 formation. Similar yields of spirolactones $\mathbf{6 , 8}$ were obtained by addition of dimethyl acetylenedicarboxylate to 5-bromo functionalized isatins 5,7. However, reaction of $N$-butyl isatin 9 resulted in formation of an inseparable mixture of compounds. Treatment of $N$-benzyl isatin $\mathbf{1 0}$ and dimethyl acetylenedicarboxylate with triphenylphosphine proceeded with reduced selectivity of the spirooxindole $\mathbf{1 1}$ formation.
\end{abstract}

Keywords: spirolactones, isatins, triphenylphosphine, dimethyl acetylenedicarboxylate.

Received: March 2015/Revised final: April 2015/ Accepted: April 2015

\section{Introduction}

The widespread distribution of butenolides in naturally occurring [1-3] and synthetic bioactive substances strongly motivate an interest for improving the methodology of the selective synthesis of butenolide functionalized spirooxindoles in high yield $[4,5]$. Such developments are of interest not only for the possible total synthesis of therapeutically useful spirooxindoles [6-15], but also for the preparation of synthetic analogs [16-30] in order to improve our knowledge in structure-activity relationships [12-14, 31, 32]. So-called butenolide functionalized spirooxindoles 1 provide the most interesting subject for synthetic investigations in view of the large and ever increasing number of the members of this family which have furan-2 $(5 H)$-one 2 as a building block (Scheme 1).

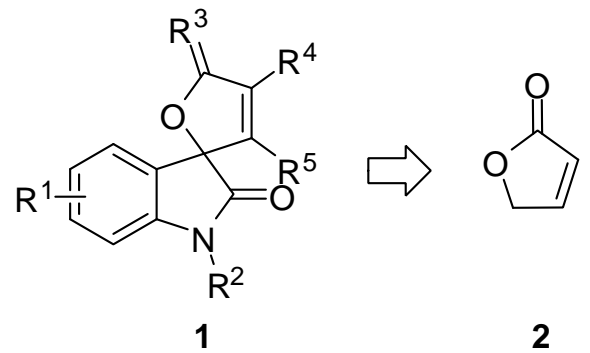

Scheme 1. Retro-synthesis of butenolide functionalized spirooxindoles.

Herein, we focused on developing of a cycloaddition method of dimethyl acetylenedicarboxylate to 5-bromo functionalized isatins for a selective construction of spiro-butenolide oxindoles $\mathbf{1}$ featuring several functionalized centres.

\section{Results and discussion}

It has been reported [4] that mixture of equal amount of $N$-ethyl isatin 3, dimethyl acetylenedicarboxylate and triphenylphosphine is a satisfactory system for the high yield (up to 90\%) construction of spirane 4 (Scheme 2). For this reason, our research was initiated toward the investigation of structure-reactivity relationships of $N$-alkyl isatins, acetylenedicarboxylate and triphenylphosphine to cope with such classical problem of heterocyclic chemistry. However, this approach for the synthesis of substance 4 provided a complex of products and main of them was isolated only with yield $60 \%$ by preparative TLC on silica gel.

The ${ }^{1} \mathrm{H}$ NMR spectrum of the white solid compound with m.p. $122-124^{\circ} \mathrm{C}$, has two doublets and two triplets at $\delta_{\mathrm{H}} 6.79-7.40 \mathrm{ppm}$. Moreover, product has signal of two methylene protons $\left(\delta_{\mathrm{H}} 3.67-3.90 \mathrm{ppm}\right)$ and one secondary methyl group at $\delta_{\mathrm{H}} 1.26-1.30 \mathrm{ppm}$ and singlet attributable to $\mathrm{MeO}$ group at $\delta_{\mathrm{H}} 3.55 \mathrm{ppm}$, the chemical shift of the last reflecting its attachment to a carbonyl atom. It was observed a chemical shift difference for protons position of $=\mathrm{C}-\mathrm{O}-\mathrm{Me}$ between reported [4] and our spectrum data at $\delta_{\mathrm{H}} 3.38 \mathrm{ppm}$ and $\delta_{\mathrm{H}} 4.34 \mathrm{ppm}$, respectively. Moreover, m.p. of our sample also is different with published in [4]. 
<smiles>[R]CN1C(=O)C(=O)c2cc([R1])ccc21</smiles>

$3 \mathrm{R}^{1}=\mathrm{H}, \mathrm{R}^{2}=\mathrm{Me}$

$5 \mathrm{R}^{1}=\mathrm{Br}, \mathrm{R}^{2}=\mathrm{Me}$

$7 \mathrm{R}^{1}=\mathrm{Br}, \mathrm{R}^{2}=\mathrm{Et}$

$9 \mathrm{R}^{1}=\mathrm{Br}, \mathrm{R}^{2}=\mathrm{n}-\mathrm{Pr}$

$10 \mathrm{R}^{1}=\mathrm{Br}, \mathrm{R}^{2}=\mathrm{Ph}$

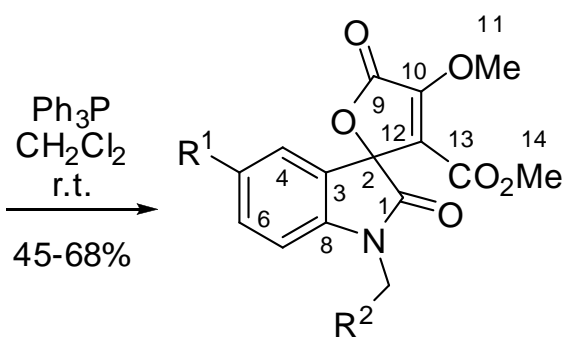

$4 \mathrm{R}^{1}=\mathrm{H}, \quad \mathrm{R}^{2}=\mathrm{Me}$

$6 \mathrm{R}^{1}=\mathrm{Br}, \mathrm{R}^{2}=\mathrm{Me}$

$8 \mathrm{R}^{1}=\mathrm{Br}, \mathrm{R}^{2}=\mathrm{Et}$

$11 \mathrm{R}^{1}=\mathrm{Br}, \mathrm{R}^{2}=\mathrm{Ph}$

Scheme 2. Synthesis of butenolide functionalized spirooxindoles.

We confirmed the structure of $\mathbf{4}$ by single-crystal X-ray analysis (see Figure 1). Monocrystals of composition $\mathrm{C}_{16} \mathrm{H}_{15} \mathrm{NO}_{6}$ belong to centrosymmetric space group $P 2 / n$, thus represent racemate. The indole moiety is orthogonal to the furan ring as indicated by the dihedral angle of $88.85(5)^{\circ}$ between them. The methyl ester group is about coplanar with furan ring and the dihedral angle between these fragments equals $10.6(1)^{\circ}$. The methoxy fragment of ester and attached to $\mathrm{C} 10$ methoxy group are in a proximate positions. Torsion angle $\mathrm{O} 6-\mathrm{C} 13-\mathrm{C} 12-\mathrm{C} 10$ equals $-12.8(3)^{\circ}$. The $\mathrm{C} 10-\mathrm{C} 12$ bond distance equals $1.343(2) \AA$ and unambiguously indicates the double character of this bond. The $\mathrm{O} 2-\mathrm{C} 9=1.353(2) \AA$ and O2-C2=1.453(2) $\AA$ distances differ due to different hybridization of bonded carbon atoms. The compound exhibits structural similarities with an already reported related structure [33-36].

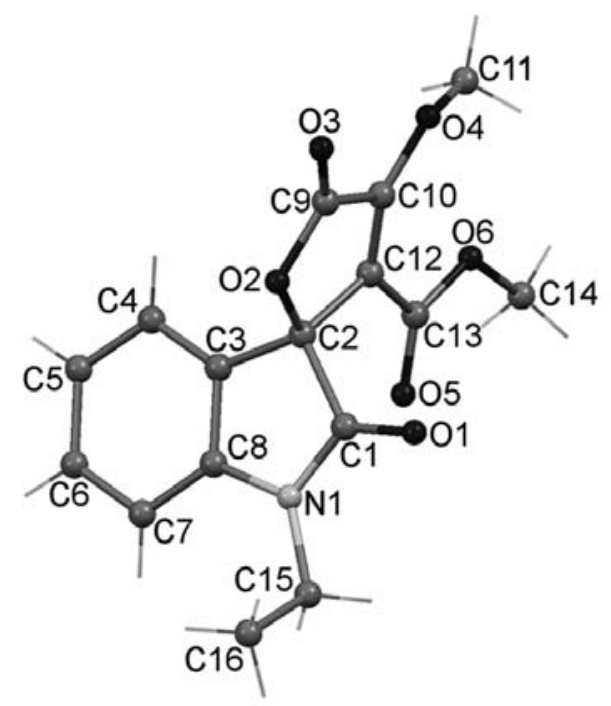

Figure 1. Single-crystal X-ray structure of 4.

Thus the major component in reaction of $N$-ethyl isatin 3, dimethyl acetylenedicarboxylate and triphenylphosphine could be formulated as 4 .

5-Bromoisatines has been reported to be a suitable derivatives of indolinedione-2,3 in synthesis of a variety of its N-substituted oxindoles [7, 8, 13, 16, 31, 32].

In our case, $N$-ethyl 5-bromoisatin 5 reacted with an equivalent of dimethyl acetylenedicarboxylate and triphenylphosphine, the crude products were obtained in $86 \%$ yield (calculated as pure 6) and $11 \%$ of initial 5 was reclaimed. The crude material was separated into fractions by column chromatography. The main product formed was characterized as methyl 5'-bromo-1'-ethyl-4-methoxy-2',5-dioxo-5H-spiro[furan-2,3'-indoline]-3-carboxylate 6. The overall yield of the crystalline material 6 with m.p. $176-179^{\circ} \mathrm{C}$ was $56 \%$. It is note that numeration of atoms in Scheme 2 is given direct in structure, that is why spectra of compounds synthesized and doesn't obey the IUPAC rules. It should be noted, also the present of two doublets attributable to $\delta_{\mathrm{H}} 6.79-6.81 \mathrm{ppm}(7 \mathrm{CH}), \delta_{\mathrm{H}} 7.24-7.25 \mathrm{ppm}(6 \mathrm{CH})$, two multiplet at $\delta_{\mathrm{H}} 3.66-3.71, \delta_{\mathrm{H}} 3.84-3.89 \mathrm{ppm}\left(\mathrm{CH}_{2}\right)$, triplet at $\delta_{\mathrm{H}} 1.26-1.30 \mathrm{ppm}\left(\mathrm{CH}_{2} \underline{\mathrm{Me}}\right)$ and two singlets at $\delta_{\mathrm{H}} 3.61 \mathrm{ppm}\left(\mathrm{CO}_{2} \mathrm{Me}\right)$ and $\delta_{\mathrm{H}} 4.37 \mathrm{ppm}(\mathrm{OMe})$. 
Condensation of 5-bromoisatine 7 with dimethyl acetylenedicarboxylate in presence of the equal amount of triphenylphosphine in dichloromethane at room temperature for 5 hours afforded the complex of products (TLC data) and methyl 5'-bromo-4-methoxy-2',5-dioxo-1'-propyl-5H-spiro[furan-2,3'-indoline]-3-carboxylate 8 was isolated in $50 \%$ yield (from compound 7) by column chromatography on silica gel. This compound gave a ${ }^{1} \mathrm{HNMR}$ spectrum $\delta_{\mathrm{H}}$ 0.97-1.00 ppm $\left(\mathrm{CH}_{2} \underline{\mathrm{Me}}\right), \delta_{\mathrm{H}} 1.68-1.74\left(\mathrm{CH}_{2} \mathrm{Me}\right), \delta_{\mathrm{H}} 3.63-3.68,3.72-3.75\left(\mathrm{~N}_{-} \mathrm{CH}_{2}\right), \delta_{\mathrm{H}} 3.62 \mathrm{ppm}\left(\mathrm{CO}_{2} \mathrm{Me}\right), \delta_{\mathrm{H}} 4.36 \mathrm{ppm}$ $(\mathrm{COMe}), \delta_{\mathrm{H}} 6.78-6.80 \mathrm{ppm}(7 \mathrm{CH}), \delta_{\mathrm{H}} 7.23-7.24 \mathrm{ppm}(6 \mathrm{CH}), \delta_{\mathrm{H}} 7.48-7.51 \mathrm{ppm}(4-\mathrm{CH})$, which was in agreement with the structure 8.

There has been no study of the stereochemistry of the atom C(2) of the spiro compound $\mathbf{8}$ by X-ray crystallography. The structure of $\mathbf{8}$ was also unambiguously confirmed by single crystal X-ray analysis. Monoclinic crystals of $\mathbf{8}$ have composition $\mathrm{C}_{17} \mathrm{H}_{16} \mathrm{BrNO}_{6}$ and crystallize in centrosymmetric space group $P 2_{1} / n$. View of molecule is shown on Figure 2. The five-membered furan ring forms dihedral angle of $86.6(1)^{\circ}$ with planar indole moiety and coplanar with methyl ester making a dihedral angle of $2.8(3)^{\circ}$. In contrast to structure of $\mathbf{4}$ the methoxy fragment of ester and attached to C10 methoxy group are in distant positions. Torsion angle O6-C13-C12-C10 equals $-175.5(3)^{\circ}$. The $\mathrm{O} 2-\mathrm{C} 9=1.362(4) \AA$, $\mathrm{O} 2-\mathrm{C} 2=1.449(4) \AA$, and $\mathrm{C} 10-\mathrm{C} 12=1.335(5) \AA$ bond distances are well agree with those found in the structure of 4 . The other geometrical parameters of $\mathbf{8}$ and $\mathbf{4}$ are in well agreement too.

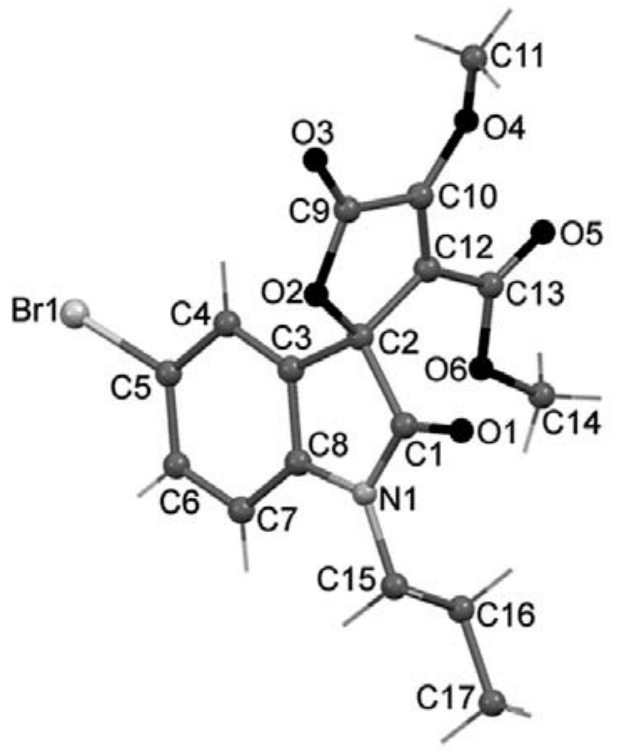

Figure 2. Single-crystal X-ray structure of 8.

Taking into account the previous experimental data (formation of the compounds $\mathbf{4 , 6 , 8}$ ) we introduced one more $\mathrm{CH}_{2}$ group in substrate (compound 9) for obtaining the similar spirocyclic oxindole-butenolide derivative. But the reaction in the same conditions gave a complex of products without target butenolide, even standing at room temperature for a week.

Based on these results it is concluded that reaction of isatin $\mathbf{9}$ with reagents occurs slowly and is not selective. The opposite situation is observed in the case of spirolactone formation $\mathbf{1 1}$ from isatin $\mathbf{1 0}$ during one hour, which was indeed a major product (67\% yield).

If the structure of product is $\mathbf{1 1}, \mathrm{CH}_{2}$ group of the derived oxindole-butenolide with m.p. $188-190^{\circ} \mathrm{C}$ should give rise to an two doublets in the ${ }^{1} \mathrm{H}$ NMR spectrum while in low field shown two protons. In fact the product shows a clear doublet $\left(\delta_{\mathrm{H}} 3.75 \mathrm{ppm}\right)$ with a spin-spin coupling $\left(J_{\mathrm{AB}}=16 \mathrm{~Hz}\right)$ of the magnitude predicted for a methylene group between the phenyl and amide fragments.

Second, the values of the chemical shifts of the phenylic $\left(\delta_{\mathrm{H}} 7.28-7.32,7.35-7.36 \mathrm{ppm}\right)$ and aromatic $\left(\delta_{\mathrm{H}} 7.00-\right.$ 7.01, 7.56-7.59, 7.89-7.90 ppm) protons are closely with those expected for spirane 11. Third, the evidence of such structural features like C-Br bonding $\left(v_{\max } 600 \mathrm{~cm}^{-1}\right)$, conjugated cyclic keto-ester $\left(v_{\max } 1732.4 \mathrm{~cm}^{-1}\right)$, amide $\left(v_{\max } 1652\right.$ $\left.\mathrm{cm}^{-1}\right)$, conjugated ether $\left(v_{\max } 1229.5 \mathrm{~cm}^{-1}\right)$, methylene group $\left(v_{\max } 1484.4 \mathrm{~cm}^{-1}\right)$ in the IR spectrum led us to consider structure 11 .

The synthesis of the polyfunctionalized spirolactones from the $\mathrm{C} 4, \mathrm{C} 6, \mathrm{C} 7$ as well as $\mathrm{N}$-substituted isatines is in progress and the results will be presented later along with a detailed discussion of the pathways to the various products. However, a provisional scheme which satisfactorily explains the production of discussed spirocyclic oxindolebutenolides is outlined (Scheme 3).

The construction of spirocyclic oxindole-butenolides involves a formation vinyltriphenylphosphonium salt $[4,38,39]$ and concomitant addition to activated carbonyl atom of starting isatins. 


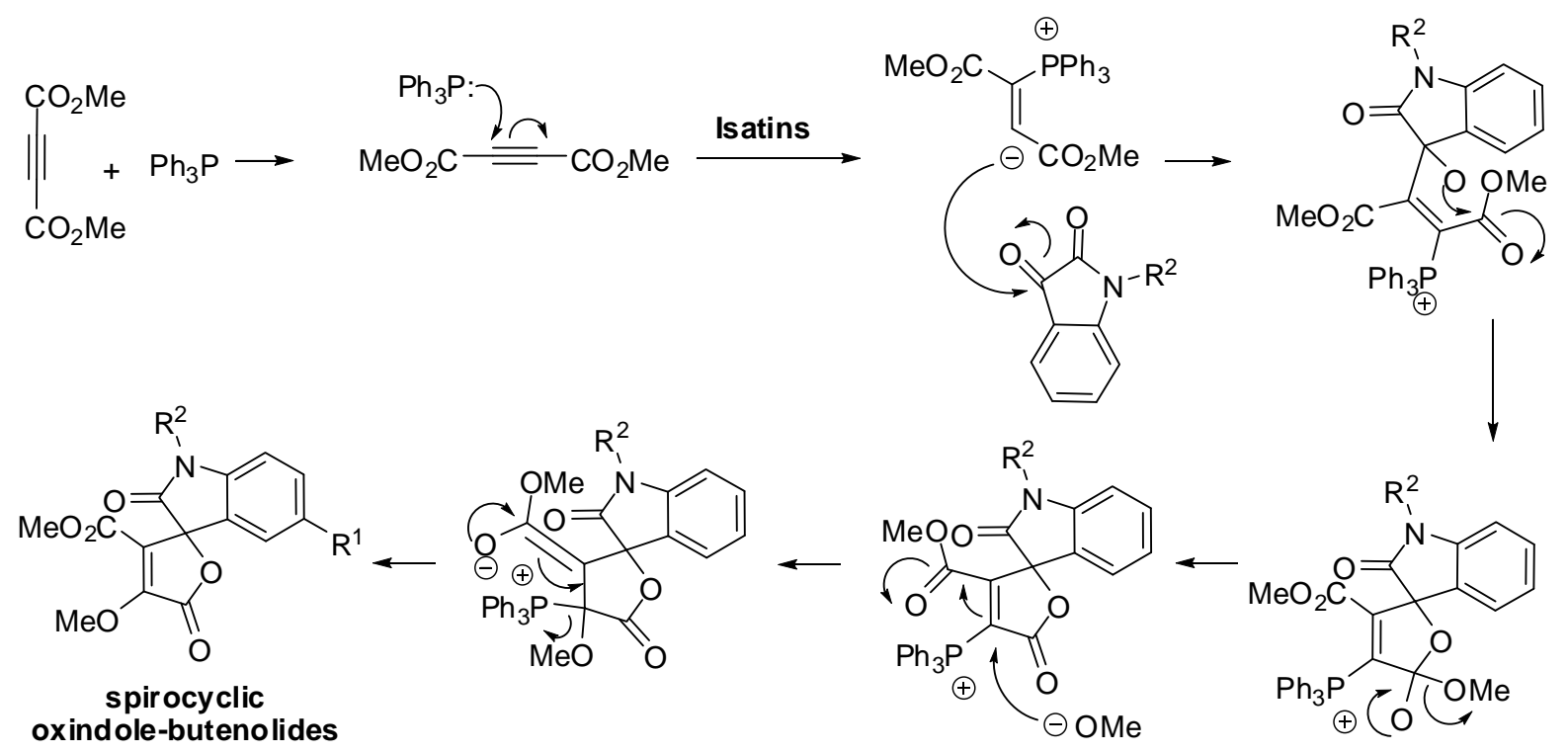

Scheme 3. The formation of spirocyclic oxindole-butenolides.

\section{Conclusions}

In conclusion, we contend that the above-described synthesis of 5-bromo substituted oxindoles linkages in spirocyclic butenolides exhibit relatively dependence of the structure-reactivity relationships of $N$-substituted isatines, dimethyl acetylenedicarboxylate. In the future it is planned to use chiral phosphine to provide the corresponding optically active spirolactones.

\section{Experimental methods}

All used solvents were of reagent quality, and all commercial reagents were used without additional purification. Removal of all solvents was carried out under reduced pressure. Analytical TLC plates were Silufol ${ }^{\circledR}$ UV-254 (Silpearl on aluminium foil, Czecho-Slovakia). IR spectra were recorded on a Spectrum 100 FT-IR spectrophotometer (Perkin -Elmer) using the universal ATR sampling accessory. ${ }^{1} \mathrm{H}$ and ${ }^{13} \mathrm{C}$ NMR spectra have been recorded for $\mathrm{CDCl}_{3} 2-\%$ solution on a "Bruker -Avance III" (400.13 and 100.61 MHz).

Isatines 3, 5, 7, 9, 10 were prepared using the methods $[13,40]$.

General procedure for the synthesis of methyl 2',5-dioxo-5 $\mathrm{H}$-spiro[furan-2,3'-indoline]-3-carboxylate 4, 6, 8, 11. To a solution of triphenylphosphine $(0.262 \mathrm{~g}, 0.001 \mathrm{~mol})$ in $5 \mathrm{~mL} \mathrm{CH}_{2} \mathrm{Cl}_{2}$ was added $\mathrm{N}$-substituted isatin $(0.001$ $\mathrm{mol})$. The mixture was cooled to $10^{\circ} \mathrm{C}$, and then dimethyl acetylenedicarboxylate $(0.142 \mathrm{~g}, 0.001 \mathrm{~mol})$ was added. The reaction mixture was stirred for about $1-5$ hours while maintaining the temperature to $25^{\circ} \mathrm{C}$. The solvent was removed in vacuum, oil like mass obtained was separated into fractions by preparative TLC on silica gel.

Methyl 1'-ethyl-4-methoxy-2',5-dioxo-5H-spiro[furan-2,3'-indoline]-3-carboxylate 4.

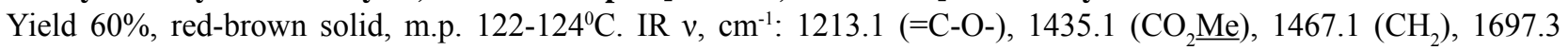
$(\mathrm{N}-\mathrm{C}=\mathrm{O}), 1726.6$ (conjugated cyclic keto-carboxylic ester), $2878.4\left(\underline{\mathrm{Me}}-\mathrm{CH}_{2}\right) .{ }^{1} \mathrm{H}$ NMR $\delta$, ppm, J/Hz: 1.26-1.30 t $(\underline{\mathrm{Me}}-$ $\left.\mathrm{CH}_{2}, 3 \mathrm{H}, J=16 \mathrm{~Hz}\right), 3.67-3.76 \mathrm{~m}\left(1 \mathrm{H}, \mathrm{CH}_{2}\right), 3.82-3.90 \mathrm{~m}\left(1 \mathrm{H}, \mathrm{CH}_{2}\right), 3.55 \mathrm{~s}\left(3 \mathrm{H}, \mathrm{CO}_{2} \mathrm{Me}\right), 4.34 \mathrm{~s}(3 \mathrm{H},=\mathrm{C}-\mathrm{OMe}), 6.79-$ $6.81 \mathrm{~d}(1 \mathrm{H}, 7 \mathrm{CH}, J=8 \mathrm{~Hz}), 6.89-6.91 \mathrm{~d}(1 \mathrm{H}, 4 \mathrm{CH}, J=8 \mathrm{~Hz}), 7.01-7.05 \mathrm{t}(1 \mathrm{H}, 5 \mathrm{CH}, J=16 \mathrm{~Hz}), 7.36-7.40 \mathrm{t}(1 \mathrm{H}, 6 \mathrm{CH}$, $J=16 \mathrm{~Hz}) .{ }^{13} \mathrm{C}$ NMR, $\delta$, ppm: $12.32\left(\underline{\mathrm{Me}}-\mathrm{CH}_{2}\right), 35.46\left(\mathrm{CH}_{2}\right), 55.25$ (C14), 60.44 (C11), 81.73 (C2), 109.17 (C7), 119.19 (C12), 123.20 (C6), 124.47 (C5), 128.20 (C3), 131.70 (C4), 143.97 (C8), 149.49 (C13), 160.55 (C10), 165.67 (C9), 169.56 (C1). Found, \%: C 60.55; H 4.59; N 4.32. $\mathrm{C}_{16} \mathrm{H}_{15} \mathrm{NO}_{6}$. Calculated, \%: C 60.57; H 4.77; N 4.41.

Methyl 5'-bromo-1'-ethyl-4-methoxy-2',5-dioxo-5H-spiro[furan-2,3'-indoline]-3-carboxylate 6.

Yield 56\%, yellow-brown solid, m.p. 176-179 ${ }^{\circ} \mathrm{C}$. IR v, $\mathrm{cm}^{-1}: 600(\mathrm{CBr}), 1228.4$ (=C-O-), $1435.9\left(\mathrm{CO}_{2} \mathrm{Me}\right), 1484.5\left(\mathrm{CH}_{2}\right)$, $1663.1(\mathrm{~N}-\mathrm{C}=\mathrm{O}), 1720.8$ (conjugated cyclic keto-carboxylic ester), $2873.0\left(\mathrm{Me}^{-\mathrm{CH}_{2}}\right) .{ }^{1} \mathrm{H}$ NMR $\delta$, ppm, $J / \mathrm{Hz}: 1.26-1.30$ $\mathrm{t}\left(\mathrm{Me}_{-} \mathrm{CH}_{2}, 3 \mathrm{H}, J=16 \mathrm{~Hz}\right), 3.66-3.71 \mathrm{~m}\left(1 \mathrm{H}, \mathrm{CH}_{2}\right), 3.84-3.89 \mathrm{~m}\left(1 \mathrm{H}, \mathrm{CH}_{2}\right), 3.61 \mathrm{~s}\left(3 \mathrm{H}, \mathrm{CO}_{2} \mathrm{Me}\right), 4.37 \mathrm{~s}(3 \mathrm{H},=\mathrm{C}-\mathrm{OMe})$, 6.79-6.81 d $(1 \mathrm{H}, 7 \mathrm{CH}, J=8 \mathrm{~Hz}), 7.24-7.25 \mathrm{~d}(1 \mathrm{H}, 6 \mathrm{CH}, J=4 \mathrm{~Hz}), 7.49-7.52 \mathrm{dd}(1 \mathrm{H}, 4 \mathrm{CH}, J=4 \mathrm{~Hz}, J=4 \mathrm{~Hz}) .{ }^{13} \mathrm{C}$ NMR, $\delta$, ppm: $12.13\left(\mathrm{Me}_{-} \mathrm{CH}_{2}\right), 35.63\left(\mathrm{CH}_{2}\right), 52.40$ (C14), 60.49 (C11), 81.08 (C2), 110.60 (C7), 115.62 (C12), 118.69 (C5), 125.33 (C3), 127.67 (C6), 134.49 (C4), 143.12 (C8), 149.59 (C13), 160.36 (C10), 165.21 (C9), 169.16 (C1). Found, \%: $\mathrm{C} 48.52 ; \mathrm{H} 3.77 ; \mathrm{N} 3.61 . \mathrm{C}_{16} \mathrm{H}_{14} \mathrm{BrNO}_{6}$. Calculated, \%: C 48.50; H 3.56; $\mathrm{N} 3.54$.

Methyl 5'-bromo-4-methoxy-2',5-dioxo-1'-propyl-5H-spiro[furan-2,3'-indoline]-3-carboxylate 8.

Yield 50\%, red solid, m.p. 90-100 ${ }^{\circ} \mathrm{C}$. IR v, $\mathrm{cm}^{-1}: 595$ (CBr), 1231.9 (=C-O-), $1435.4\left(\mathrm{CO}_{2} \underline{\mathrm{Me}}\right), 1485.2\left(\mathrm{CH}_{2}\right), 1659.5$ $(\mathrm{N}-\mathrm{C}=\mathrm{O}), 1719.8$ (conjugated cyclic keto-carboxylic ester), $2878.0\left(\underline{\mathrm{Me}}-\mathrm{CH}_{2}\right) .{ }^{1} \mathrm{H}$ NMR $\delta, \mathrm{ppm}, J / \mathrm{Hz}$ : 0.97-1.00 t $(\underline{\mathrm{Me}}-$ $\left.\mathrm{CH}_{2}, 3 \mathrm{H}, J=12 \mathrm{~Hz}\right), 1.68-1.74 \mathrm{~m}\left(2 \mathrm{H}, \mathrm{Me}-\mathrm{CH}_{2}\right), 3.63-3.68 \mathrm{~m}\left(1 \mathrm{H}, \mathrm{N}-\mathrm{CH}_{2}\right), 3.72-3.75 \mathrm{~m}\left(1 \mathrm{H}, \mathrm{N}-\mathrm{CH}_{2}\right), 3.62 \mathrm{~s}(3 \mathrm{H}$, 
$\left.\mathrm{CO}_{2} \mathrm{Me}\right), 4.36 \mathrm{~s}(3 \mathrm{H},=\mathrm{C}-\mathrm{OMe}), 6.78-6.80 \mathrm{~d}(1 \mathrm{H}, 7 \mathrm{CH}, J=8 \mathrm{~Hz}), 7.23-7.24 \mathrm{~d}(1 \mathrm{H}, 6 \mathrm{CH}, J=4 \mathrm{~Hz}), 7.48-7.51 \mathrm{dd}(1 \mathrm{H}$,

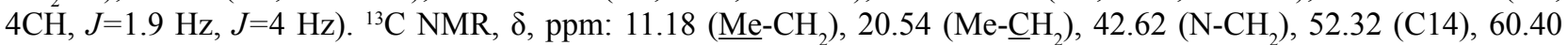
(C11), 81.07 (C2), 110.88 (C7), 111.95 (C12), 115.52 (C5), 125.25 (C3), 127.52 (C6), 134.41 (C4), 143.57 (C8), 149.50 (C13), 160.46 (C10), 165.13 (C9), 169.16 (C1). Found, \%: C 49.58; H 4.11; N 3.61. $\mathrm{C}_{17} \mathrm{H}_{16} \mathrm{BrNO}_{6}$. Calculated, \%: C 49.77; H 3.93; N 3.41.

\section{Methyl 1'-benzyl-5'-bromo-4-methoxy-2',5-dioxo-5H-spiro[furan-2,3'-indoline]-3-carboxylate 11.}

Yield 67\%, yellow solid, m.p. 188-190 ${ }^{\circ} \mathrm{C}$. IR v, $\mathrm{cm}^{-1}$ : 585 (CBr), 1229.5 (=C-O-), $1430.2\left(\mathrm{CO}_{2} \underline{\mathrm{Me}}\right), 1484.4\left(\mathrm{CH}_{2}\right)$, $1652.3(\mathrm{~N}-\mathrm{C}=\mathrm{O}), 1732.4$ (conjugated cyclic keto-carboxylic ester), $2902.1\left(\underline{\mathrm{Me}}-\mathrm{CH}_{2}\right) .{ }^{1} \mathrm{H}$ NMR $\delta$, ppm, J/Hz: $3.49 \mathrm{~s}$ $\left(3 \mathrm{H}, \mathrm{CO}_{2} \mathrm{Me}\right), 4.30 \mathrm{~s}(3 \mathrm{H},=\mathrm{C}-\mathrm{OMe}), 4.87-4.91 \mathrm{~d}\left(1 \mathrm{H}, \mathrm{CH}_{2}, J=16 \mathrm{~Hz}\right), 5.01-5.05 \mathrm{~d}\left(1 \mathrm{H}, \mathrm{CH}_{2}, J=16 \mathrm{~Hz}\right), 7.00-7.01 \mathrm{~d}$ $(1 \mathrm{H}, 7 \mathrm{CH}, J=4 \mathrm{~Hz}), 7.56-7.59 \mathrm{dd}(1 \mathrm{H}, 6 \mathrm{CH}, J=4 \mathrm{~Hz}, J=4 \mathrm{~Hz}), 7.89-7.90 \mathrm{~d}(1 \mathrm{H}, 4 \mathrm{CH}, J=4 \mathrm{~Hz}, J=4 \mathrm{~Hz}) .{ }^{13} \mathrm{C}$ NMR, $\delta$, ppm: $44.09\left(\mathrm{CH}_{2}\right), 52.86(\mathrm{C} 14), 60.97(\mathrm{C} 11), 81.09$ (C2), 115.65 (C7), 112.73 (C12), 117.47 (C5), 129.25 (C3), 127.76, 128.27, 128.70 (benzylic), 135.60 (C6), 134.84 (C4), 143.49 (C8), 150.43 (C13), 160.74 (C10), 165.61 (C9), 170.16 (C1). Found, \%: C 55.21; H 3.71; N 2.87. $\mathrm{C}_{21} \mathrm{H}_{16} \mathrm{BrNO}_{6}$. Calculated, \%: C 55.04; H 3.52; N 3.06.

\section{Crystal structure determination}

The X-ray data for $\mathbf{4}$ and $\mathbf{8}$ were collected at room temperature on an Oxford Diffraction Xcalibur-E diffractometer equipped with CCD area detector and a graphite monochromator utilizing MoK $\alpha$ radiation. The final unit cell dimensions were obtained and refined on an entire data set. The structures were solved by direct methods using SHELX-97 program package [41] and refined with full-matrix least squares method with anisotropic thermal parameters for the non-hydrogen atoms.

In both structures the $\mathrm{C}\left(s p^{2}\right)$-bound $\mathrm{H}$ atoms and methylene groups $\mathrm{H}$ atoms were placed in calculated positions and were treated using AFIX 43 and AFIX 23 instructions, respectively, and a model approximation with Uiso $(\mathrm{H})=$ $1.2 \mathrm{Ueq}(\mathrm{C})$, the $\mathrm{H}$ atoms of methyl groups were found and refined using AFIX 137 instruction and $\mathrm{Uiso}(\mathrm{H})=1.5 \mathrm{Ueq}(\mathrm{C})$. The figures were produced using MERCURY [38].

The X-ray data and the details of the refinement for $\mathbf{4}$ and $\mathbf{8}$ are summarized in Table 1.

Crystallographic data for new structures reported herein were deposited with the Cambridge Crystallographic Data Centre and allocated the deposition numbers CCDC 1053146 and CCDC 1053147. These data can be obtained free of charge from the Cambridge Crystallographic Data Centre via www.ccdc.cam.ac.uk/data_request/cif.

Table 1

Crystal and structure refinement data for structure of 4 and 8.

\begin{tabular}{ccc}
\hline & $\mathbf{4}$ & $\mathbf{8}$ \\
\hline Empirical formula & $\mathrm{C}_{16} \mathrm{H}_{15} \mathrm{NO}_{6}$ & $\mathrm{C}_{17} \mathrm{H}_{16} \mathrm{NO}_{6} \mathrm{Br}$ \\
Formula weight & 317.29 & 410.22 \\
Temperature $(\mathrm{K})$ & $293(2)$ & $293(2) \mathrm{K}$ \\
Crystal system & Monoclinic & Monoclinic \\
Space group & $P 2_{1} / n$ & $P 2_{1} / n$ \\
$Z$ & 4 & 4 \\
Unit cell dimensions & & \\
$a(\AA)$ & $11.4801(4)$ & $9.5655(7)$ \\
$b(\AA)$ & $8.4072(3)$ & $18.1782(7)$ \\
$c(\AA)$ & $15.5386(6)$ & $11.0198(6)$ \\
$\alpha(\mathrm{deg})$ & 90 & 90 \\
$\beta(\mathrm{deg})$ & $96.723(3)$ & $114.592(8)$ \\
$\gamma(\mathrm{deg})$ & 90 & 90 \\
$V\left(\AA^{3}\right)$ & $1489.41(9)$ & $1742.4(2)$ \\
$D_{\mathrm{c}}\left(\mathrm{g} / \mathrm{cm}^{-3}\right)$ & 1.415 & 1.564 \\
$\left.\mu(\mathrm{mm})^{-1}\right)$ & 0.110 & 2.392 \\
$F(000)$ & 664 & 832 \\
Reflections collected & $4988 / 2607$ & $6088 / 3067$ \\
Independent reflections & 1852 & 2207 \\
Data/restraints/parameters & $2607 / 0 / 211$ & $3067 / 0 / 229$ \\
Goodness-of-fit on $F^{2}$ & 1.000 & 1.000 \\
$R_{1}, w R_{2}[I 2 \sigma(I)]$ & $0.0347,0.0826$ & $0.0462,0.1133$ \\
$R_{1}, w R_{2}($ all data) & $0.0535,0.0865$ & $0.0727,0.1252$ \\
Largest difference in peak and hole $\left(\mathrm{e} \AA^{-3}\right)$ & 0.141 and -0.153 & 0.870 and -0.515 \\
\hline
\end{tabular}

\section{Acknowledgments}

We thank the bilateral Moldova-Ukraine projects (Ref. No. 14.820.18.02.06/U and Ref. No. M/129-2014) for financial support. 


\section{References}

1. Wright, A.D.; Nys, R.; Angerhofer, C. K.; Pezzuto, J.M.; Gurrath, M. Biological activities and 3D QSAR studies of a series of Delisea pulchra (cf. fimbriata) derived natural products. Journal of Natural Products, 2006, 69, pp. 1180-1187.

2. Mansoor, T.A.; Hong, J.; Lee, C.O.; Sim, C. J.; Im, K.S.; Lee, D.S.; Jung, J. H. New Cytotoxic Metabolites from a Marine Sponge Homaxinella sp. Journal of Natural Products, 2004, 67, pp. 721-724.

3. Grossmann, G.; Poncioni, M.; Bornand, M.; Jolivet, B.; Neuburger, M.; Sequin U. Bioactive butenolides from Streptomyces antibioticus TU" 99: absolute configurations and synthesis of analogs. Tetrahedron, 2003, 59, pp. 3237-3251.

4. Esmaili, A.A.; Bodaghi, A. New and efficient one-pot synthesis of functionalized $\gamma$-spirolactones mediated by vinyltriphenylphosphonium salts. Tetrahedron, 2003, 59, pp. 1169-1171.

5. Yavari, I.; Hossaini, Z.; Sabbaghan, M.; Ghazanfarpour-Darjani, M. Efficient synthesis of functionalized spiro-2,5dihydro-1,2- $\gamma$-oxaphospholes. Tetrahedron, 2007, 63, 9423-9428.

6. Santos, M.M.M. Recent advances in the synthesis of biologically active spirooxindoles. Tetrahedron, 2014, 70, pp. 9735-9757.

7. Macaev, F.; Geronikaki, A.; Sucman, N. Recent application of isatins in synthesis of functionalized spirocyclic oxindoles. In Targets in heterocyclic systems. Chemistry and Properties. O. A. Attanasi D. Spinelli. Eds. Società Chimica Italiana: Pesaro-Urbino, 2011, Vol. 15, pp. 294-326.

8. Macaev F. Synthesis of spiroindolin-2-ones from $1 H$-indole-2,3-dione. Selected methods for synthesis and modification of heterocycles. The chemistry of synthetic indole systems. InterBioScreen press: Moscow, 2004, Vol. 3, pp. 75-102.

9. Millemaggi, A.; Taylor, R.J.K. 3-Alkenyl-oxindoles: Natural products, pharmaceuticals, and recent synthetic advances in tandem/telescoped approaches. European Journal of Organic Chemistry, 2010, 24, pp. 4527-4547.

10. Kumar, A., Chimni, S.S. Catalytic asymmetric synthesis of 3-hydroxyoxindole: a potentially bioactive molecule. RSC Advances, 2012, 2, pp. 9748-9762.

11. Aleman, J.; Cabrera, S. Application of asymmetric organocatalysis in medicinal chemistry. Chemical Society Reviews, 2013, 42, pp. 774-793.

12. Sucman, N.; Macaev, F. Process for obtaining of derivatives of carbonitril spirocyclopropanoxindoles. MD Patent, 2012, No. 4201 (in Romanian).

13. Sucman, N. Synthesis and properties of new spirocompounds. Ph.D. Thesis, Institute of Chemistry of ASM, Chisinau, Moldova, 2013 (in Russian).

14. Sucman, N.; Macaev, F. Process for obtaining of derivatives of carbomethoxy spirocyclopropanoxindoles. MD Patent, 2012, No. 4202 (in Romanian).

15. Marti, C.; Carreira, E.M. Construction of spiro[pyrrolidine-3,3-oxindoles]: recent applications to the synthesis of oxindole alkaloids. European Journal of Organic Chemistry, 2003, 12, pp. 2209-2219.

16. Singh, G.S.; Desta, Z.Y. Isatines as privileged molecules in design and synthesis of spiro-fused cyclic frameworks. Chemical Reviews, 2012, 112, pp. 6104-6155.

17. Chauhan, P.; Chimni, S.S. Organocatalytic asymmetric synthesis of 3-amino-2-oxindole derivatives bearing a tetra-substituted stereocenter. Tetrahedron: Asymmetry, 2013, 24, pp. 343-356.

18. Ball-Jones, N.R.; Badillo, J.J.; Franz, A.K. Strategies for the enantioselective synthesis of spirooxindoles. Organic and Biomolecular Chemistry, 2012, 10, pp. 5165-5181.

19. Hong L.; Wang, R. Recent advaces in asymmetric organocatalytic construction of 3,3'-spirocyclic oxindoles. Advanced Synthesis and Catalysis, 2013, 355, pp. 1023-1052.

20. Pellissier, H. Recent developments in asymmetric organocatalytic domino reactions. Advanced Synthesis and Catalysis, 2012, 354, pp. 237-294.

21. Liu, X.; Lin, L.; Feng, X. Amide-based bifunctional organocatalysts in asymmetric reactions. Chemical Communications, 2009, 41, pp. 6145-6158.

22. Duan, J.; Li, P. Asymmetric organocatalysis mediated by primary amines derived from cinchona alkaloids: recent advances. Catalysis Science and Technology, 2014, 4, pp. 311-320.

23. Phillips, A.M.F. Applications of carbohydrate-based organocatalysts in enantioselective synthesis. European Journal of Organic Chemistry, 2015, 33, pp. 7291-7303.

24. Shen, K.; Liu, X.; Lin, L.; Feng, X. Recent progress in enantioselective synthesis of C3-functionalized oxindoles: rare earth metals take action. Chemical Science, 2012, 3, pp. 327-334.

25. Cao, Z.Y.; Wang, Y.H.; Zeng, X.P.; Zhou, J. Catalytic asymmetric synthesis of 3,3-disubstituted oxindoles: diazooxindole joins the field. Tetrahedron Letters, 2014, 55, pp. 2571-2584.

26. Nakamura, S. Catalytic enantioselective decarboxylative reactions using organocatalysts. Organic and Biomolecular Chemistry, 2014, 12, pp. 394-405. 
27. Mrowczynski, R.; Nan, A.; Liebscher, J. Magnetic nanoparticle-supported organocatalysts - an efficient way of recycling and reuse. RSC Advances, 2014, 4, pp. 5927-5952.

28. Dalpozzo, R.; Bartoli, G.; Bencivenni, G. Recent advances in organocatalytic methods for the synthesis of disubstituted 2- and 3-indolinones. Chemical Society Reviews, 2012, 41, pp. 7247-7290.

29. Dai, C.; Liang, B.; Stephenson, C.R.J. Expanding the chemical diversity of spirooxindoles via alkylative pyridine dearomatization. Beilstein Journal of Organic Chemistry, 2012, 8, pp. 986-993.

30. Gu, Y. Multicomponent reactions in unconventional solvents: state of the art. Green Chemistry, 2012, 14, pp. 20912128.

31. Radul, O.; Sucman, N.; Pogrebnoi, S.; Barba, A.; Geronikaki, A.; Macaev, F. Synthesis and antiviral activity of new thiazole, 1,2,4-triazol and oxindole derivatives. Chemistry Journal of Moldova, 2011, 6(1), pp. 101-109.

32. Noole, A.; Sucman, N. S.; Kabeshov, M.A.; Kanger, T.; Macaev, F.Z.; Malkov A.V. Highly enantio- and diastereoselective generation of two quaternary centers in spirocyclopropanation of oxindole derivatives. Chemistry: A European Journal. 2012, 18, pp. 14929-14933.

33. Gangadharan, R.; Sethusankar, K.; Kiruthika, S.E.; Perumal, P.T. Methyl 4-anilino-2',5-dioxo-1',2'-dihydro-5Hspiro[furan-2,3'-indole]-3-carboxylate. Acta Crystallographica Section E: Structure Reports Online, 2013, 69, o1055, doi:10.1107/S1600536813014967.

34. Gangadharan, R.; Kiruthika, S.E.; Sethusankar, K.; Perumal, P.T. Methyl 4-(4-bromoanilino)-2',5-dioxo-5Hspiro[furan-2,3'-indoline]-3-carboxylate. Acta Crystallographica Section E: Structure Reports Online, 2014, 70, pp. $0210-0211$.

35. Zhang, Y.; Lu, Y.; Tang, W.; Lu, T.; Du, D. Cooperative $N$-heterocyclic carbene (NHC)/Lewis acid-mediated regioselective umpolung formal [3+2] annulations of alkynyl aldehydes with isatins. Organic and Biomolecular Chemistry, 2014, 12, pp. 3009-3015.

36. Li, J.; Liu, Y.; Li, C.; Jie, H.; Jia, X. Atom-economical synthesis of the functionalized spirocyclic oxindolebutenolide via three-component [2+2+1] cycloaddition strategy. Green Chemistry, 2012, 14, pp. 1314-1321.

37. Macrae, C. F.; Edgington, P. R.; McCabe, P.; Pidcock, E.; Shields, G. P.; Taylor, R.; Towler, M.; van de Streek, J. Mercury:Visualization and Analysis of Crystal Structures. Journal of Applied Crystallography, 2006, 39, pp. 453457.

38. $\mathrm{Xu}, \mathrm{S}$;; He, Z. Recent advances in stoichiometric phosphine-mediated organic synthetic reactions. RSC Advances, 2013, 3, pp. 16885-16904.

39. Macaev, F.Z; Sucman, N.S.; Boldescu, V.V. Selective transformation of isatinsintosubstituted 2-oxindoles. Russian Chemical Bulletin, International Edition, 2014, 63, pp. 15-25.

40. Macaev, F.Z.; Radul, O.M.; Shterbet, I.N.; Pogrebnoi, S.I.; Sucman, N.S.; Malinovskii, S.T.; Barba, A.N., Gdaniec, M. Synthesis and structure of new oxoindoles. Chemistry of Heterocyclic Compounds, 2007, 43, pp. 298-305.

41. Sheldrick, G. M. A short history of SHELX. Acta Crystallographica, 2008, A64, pp. 112-122. 